\title{
Determination of the Sea Waters Quality of Tobruk-Libya Gulf
}

\author{
Gaith G. Altohame Jalgaif ${ }^{1}$, Salah Ali M. Idris ${ }^{2,}{ }^{*}$, Rabie Ali M. Maarouf ${ }^{3}$, Ahmed M. Attia ${ }^{4}$, \\ Manal M. El-Naggar ${ }^{5}$ \\ ${ }^{1}$ Marine Resources Department, Faculty of Natural Resources and Environmental Sciences, Tobruk University, Tobruk, Libya \\ ${ }^{2}$ Chemistry Department, Faculty of Science, Tobruk University, Tobruk, Libya \\ ${ }^{3}$ Oceanography Department, Faculty of Science, University of Alexandria, Alexandria, Egypt \\ ${ }^{4}$ Department of Environmental Studies, Institute of Graduate Studies and Research, University of Alexandria, Alexandria, Egypt \\ ${ }^{5}$ Marine Environmental Division, National Institute of Oceanography and Fisheries, Ministry of Scientific Research, Alexandria, Egypt
}

Email address:

salah.idris@ymail.com(S. A. M. Idris)

${ }^{*}$ Corresponding author

\section{To cite this article:}

Gaith G. Altohame Jalgaif, Salah Ali M. Idris, Rabie Ali M. Maarouf, Ahmed M. Attia, Manal M. El-Naggar. Determination of the Sea Waters Quality of Tobruk-Libya Gulf. International Journal of Environmental Chemistry. Vol. 2, No. 1, 2018, pp. 1-9. doi: $10.11648 /$ j.ijec.20180201.12

Received: April 2, 2018; Accepted: April 18, 2018; Published: May 19, 2018

\begin{abstract}
This work consists of assessing the degree of pollution caused by wastewater, Power station discharge pipe and petroleum port in the gulf of Tobruk-Libya. This study is based on the analysis of the physicochemical parameters, the parameters indicating pollution and the determination of $\mathrm{pH}, \mathrm{DO}, \mathrm{BOD}, \mathrm{OOM}$, phenol, Salinity, nutrients $\left(\mathrm{PO}_{4}, \mathrm{SiO}_{3}, \mathrm{NO}_{2}\right.$, $\mathrm{NO}_{3}$ and $\mathrm{NH}_{3}$ ), sodium and potassium on seawater samples taken from the site. The sampling was carried out during the April of year 2015. The results obtained show significant values in physicochemical parameters, pollution indicator parameters. The results of the pollution indicator parameters show the presence of important pollution at the site studied. It is clear from the determination of physicochemical parameters that the site under investigation shows a high contamination of seawater according to pollution caused by wastewater, Power station discharge pipe and petroleum port near the gulf of Tobruk-Libya. The absence of treatment and the long-term exposure to these discharges will lead to dangerous levels which maybe lead to destruction of marine life may affect people living near the port.
\end{abstract}

Keywords: Tobruk Gulf, Marine Pollution, Physicochemical Parameters, Pollution Indicators

\section{Introduction}

Every year, pollution of seawater is gaining more attention according to serious health problems may be caused by direct contact with seawater. Even beaches allowed for swimming are not totally clean. Water is one of the essential elements for most large industrial enterprises. After being used, most of this wastewater is returned to the environment [1]. As it is usually loaded with organic matter, it becomes a major source of pollution for the environment that receives it [2].

Some of water quality parameters like colour, turbidity, temperature, salinity, conductivity, dissolved oxygen; radioactivity and suspended solids have been used as indicators of physical data which is vital for the proper management of the marine environment [3]. Changes in the physico-chemical parameters in coastal waters have been attributed to human activities. Variation in some of the physical and chemical parameters such as rainfall, temperature, salinity, nitrate-nitrogen, phosphate-phosphorus, sulphate, biological oxygen demand and chemical oxygen demand have been reported to influence phytoplankton abundance [4]. According to Suthers and Rissik [5], the major limiting nutrients for phytoplankton are nitrogen in form of ammonium $\left(\mathrm{NH}_{4}\right)$, nitrite $\left(\mathrm{NO}_{3}\right)$ and phosphate $\left(\mathrm{PO}_{3}\right)$. Nitrogen tends to be the limiting nutrients in marine systems, while phosphate is the limiting nutrient in the 
freshwater systems [5]. Environmental conditions that regulate phytoplankton composition are temperature, salinity, nutrient concentrations or nutrient availability, weight ratio of inorganic nitrogen to inorganic phosphorus [6-8].

The Libyan coast would undoubtedly deserve a little more attention from public authorities and citizens. The coastline of the Tobruk gulf is increasingly attacked today by various forms of nuisance due to industrial activity and massive urbanization, resulting in an ever-increasing extent of pollution from domestic and Industrial development. The coastal fringe is increasing wastewater discharge without any treatment, causing biological and physicochemical contamination of marine waters. This coastal fringe is experiencing a galloping population expansion accompanied by anarchic urbanization and intense port associated with various industrial activities, which have consequences for the coastal environment. In recent years, three of pollution sources discharges there waste in Tobruk gulf. The large slabs of petrochemicals presented along the coast off the industrial poles of Tobruk causing adverse effects on marine fauna and flora. In this study, the impact of effluent discharges on aquatic receptor has studied and measured the main parameters of this pollution.

\section{Selection and Description of Study Area}

Tobruk is a port city on Libya's eastern Mediterranean coast. It is the capital of the Butnan District (formerly Tobruk District) and has a population of 120,000 (2011 est.). The Port of Tobruk is a port located in Eastern Libya near the Egyptian border - about $450 \mathrm{~km}$ east of Benghazi. The Tobruk gulf and adjacent marine environment are under risk of discharged wastewaters from drains, ballast water and oil port located in Tobruk gulf. These pollutants cause dysfunctions in the food web that might lead a total ecosystem imbalance, especially because of the low water exchange rate with the open sea. In this study 15 sites in the Tobruk gulf has chosen to investigate the level of pollution maybe reached in this gulf (Figure 1). Samples were collected from 1: Diving club; 2: San Jorge beach; 3: Old Braga Jetty; 4: Navy center; 5: Civil; 6: Sewage discharge tube(1 and 2); 7: Cornish beach center (Sewage discharge tube(3)); 8: Gulf Hotel (Small Sewage discharge tube 4); 9: Old cool port; 10: Fishing port; 11: Power station site; 12: New Braga Jetty for petroleum refinery products; 13: Heraga Jetty for crude oil loading; 14: Suction Box for power station; 15: Umm El-Shawesh transit during April.

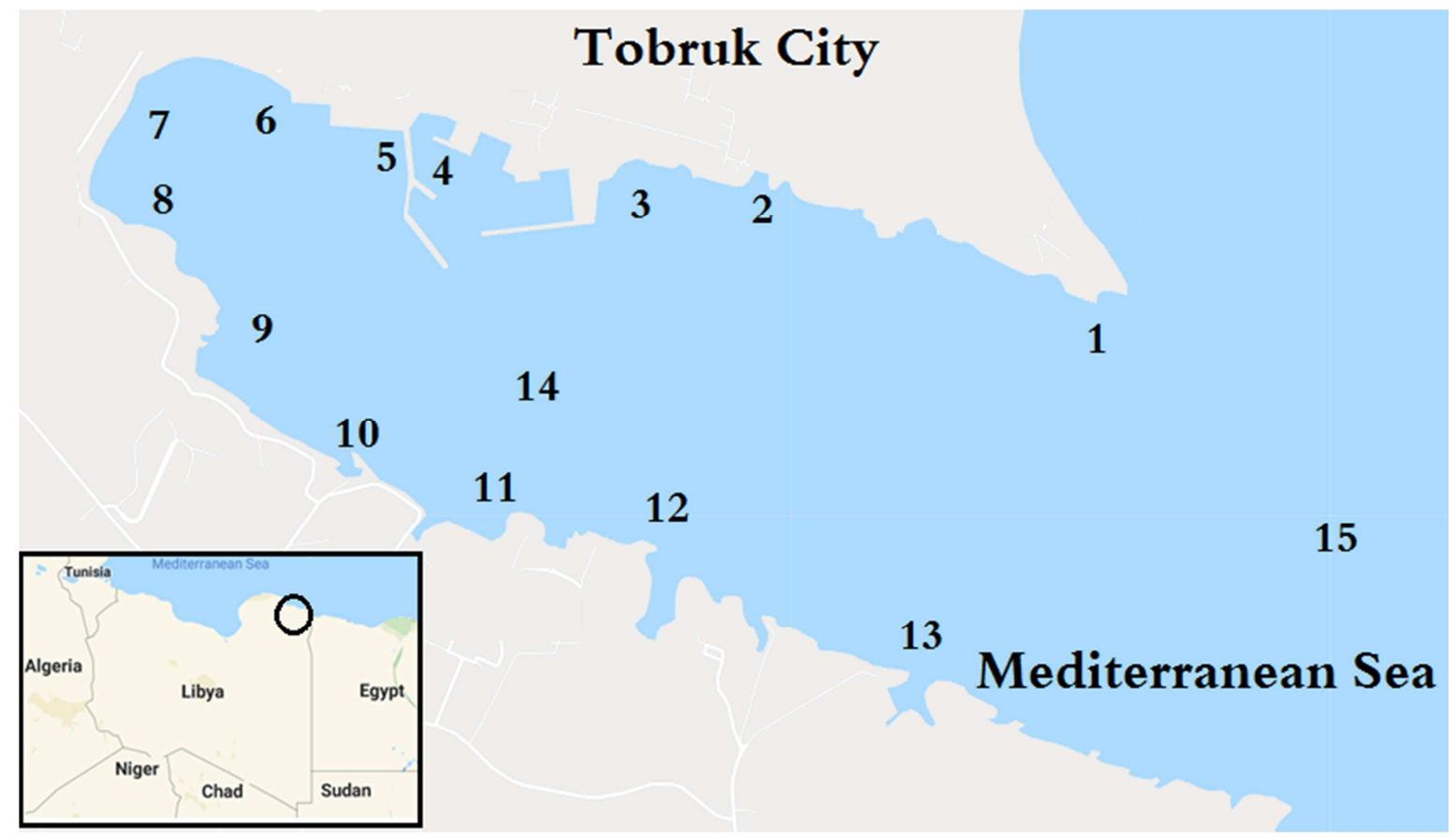

Figure 1. Tobruk gulf and sampling sites map.

\section{Materials and Methods of Analysis}

\section{1. pH and Transparency (Secchi Depth) of Seawater}

The $\mathrm{pH}$ value was determined by "Inolab $\mathrm{pH}$ meter 720 " which equipped with a temperature compensating device. The instrument was calibrated using standard $\mathrm{pH}$ buffers (4, 7 and 10).

Seawater transparency (Secchi depth) was determined according to reference [9]. Briefly, the observer should try to ensure that the measuring rope stays in an as upright position as possible. Measure the Secchi depth on the shaded side of the ship to avoid direct sunlight reflections from the water surface. However, the observer has to consider the source of error in the shaded side that occurs whenever the Secchi depth stretches beyond the shade of the ship. In this case, the disk (A white disk with a diameter of $30 \mathrm{~cm}$. The disk should weigh at least $1.7 \mathrm{~kg}$ ) is suddenly lighted by the sun and a 
higher reading will be attained. Allow sufficient time (preferably $2 \mathrm{~min}$ ) when looking at the disc near its extinction point for the eyes to completely adapt to the prevailing luminance level. Lower the disc further until it is no longer visible. The achieved depth is to be read and written down. After that, the disc is lowered by another 0.5 $\mathrm{m}$. Then, during a slow elevation, the disc becomes visible as a greenish-bluish spot. The achieved depth is to be read and written down. It is recommended to repeat the test two times as a minimum. The Secchi depth is the arithmetic average of all readings.

\subsection{Determination of Dissolved Oxygen (DO) and Biological Oxygen Demand (BOD)}

Determination of DO and BOD in this work is according to Ref. [10]. BOD bottles (biological oxygen demand) are rinsed twice with the sample being analysed. Water is allowed to overflow from the top of the BOD bottle which is stoppered at once. A volume of water at least equal to the volume of the BOD bottle should be allowed to overflow. When the sample is taken from a bucket (e.g. surface samples), the bottle was rinsed twice and then allowed the water to flow in by submerging the bottle to the mouth and gently tipping it so that the sample enters with no bubbling and a minimum of turbulence. The sampling delay should never exceed $15 \mathrm{~min}$. When the bottles are filled the analysis should be commenced in less than $1 \mathrm{hr}$ as oxygen may be lost when the samples warm to room temperature or by microbiological respiration. The samples was then Stored in the dark or in subdued light to minimize photosynthesis. For BOD the analysis should be done after exact one week.

During the analysis, the stopper from the BOD bottle was Removed and $1.0 \mathrm{~mL}$ of manganous sulphate reagent (480 g of manganous sulphate tetrahyde in $1 \mathrm{~L}$ distilled water) was added with an automatic pipette followed at once by $1.0 \mathrm{~mL}$ of alkaline iodide solution (mix $500 \mathrm{~g}$ of sodium hydroxide in $500 \mathrm{~mL}$ of distilled water with $300 \mathrm{~g}$ of potassium iodide in $450 \mathrm{~mL}$ of distilled water). Then the bottle immediately restoppered and the contents mixed thoroughly by shaking until the precipitated manganous-manganic hydroxide is evenly dispersed. No air bubbles should be trapped in the bottle. When the precipitate has settled slightly (in 2-3 min) shake the bottles again. Finally allow the samples to stand until the precipitate has settled at least one third of the way down the bottle leaving a clear supernatant solution. It is best practice to allow the solution to warm to room temperature at this stage. Add $1.0 \mathrm{~mL}$ of concentrated (sp gr 1.84) sulphuric acid, re-stopper the bottle and mix so that all the precipitate dissolves. No air should be trapped in the bottle. Within an hour or so of acidification transfer $50.0 \mathrm{~mL}$ of solution (100 $\mathrm{mL}$ if desired for oxygen contents less than about $0.1 \mathrm{mg}$ $\mathrm{O}_{2} /$ liter) into a specially painted conical flask by means of a pipette. Titrate at once with standard $0.01 \mathrm{~N}$ thiosulphate solution until a yellow colour disappears. Add $2 \mathrm{~mL}$ of starch indicator (10 g of soluble starch in $100 \mathrm{~mL}$ of distilled water) and conclude the titration until a light blue colour disappears.

$$
B O D \text { as } m g / L=\frac{Y}{Y-2} \times \frac{5.00}{X} \times f \times V
$$

where

$Y=$ BOD bottle Volume.

$X=$ Volume of sample from bottle $(50 \mathrm{~mL})$.

$V=$ Volume of thiosulphate solution from burette.

To calculate $f$. Fill a $300-\mathrm{mL}$ BOD bottle with sea water, or with distilled water, and add $1.0 \mathrm{~mL}$ of concentrated sulphuric acid and $1.0 \mathrm{~mL}$ of alkaline iodide solution and mix thoroughly. Finally add $1.0 \mathrm{~mL}$ of manganous sulphate solution and mix again. Withdraw approximately $50-\mathrm{mL}$ aliquots into the titration flasks. Use one or two flasks for blank determinations if necessary, and to the other add $5 \mathrm{~mL}$ of $0.01 \mathrm{~N}$ potassium iodates $(0.3567 \mathrm{~g}$ from potassium iodates in $1 \mathrm{~L}$ distilled water) from a clean $5-\mathrm{mL}$ pipette a light brown colour appears. Allow the iodine liberation to proceed for at least $2 \mathrm{~min}$ but not for more than $5 \mathrm{~min}$, during which time the solution should be at a temperature below $25^{\circ} \mathrm{C}$ and out of direct sunlight. Titrate the iodine with the appropriate thiosulphate solution $(0.01 \mathrm{~N})$ till the be a light yellow then add 3 drops from starch indicator the colour will change to blue then continue the titration till the colour disappeared.

\subsection{Determination of Oxidizable Organic Matter (OOM) [10]}

OOM was based on oxidizing the sample with permanganate solution and the produced oxides dissolved in the sample are titrated as oxygen, a $100 \mathrm{~mL}$ of water sample was boiled with $10 \mathrm{~mL}$ of alkaline $0.01 \mathrm{~N} \mathrm{KMnO}_{4}$ solution and $1 \mathrm{~mL} \mathrm{NaOH}(5 \% \mathrm{NaOH}(5 \mathrm{~g} \mathrm{NaOH}$ in $100 \mathrm{~mL}$ water $)$ for $20 \mathrm{~min}$, and then cooled to room temperature. $5 \mathrm{~mL}$ $\mathrm{H}_{2} \mathrm{SO}_{4}(9 \mathrm{~N})$ was added, followed by $1 \mathrm{~mL} \mathrm{KI}(5 \% \mathrm{KI}(5 \mathrm{~g} \mathrm{KI}$ in $100 \mathrm{~mL}$ water). The librated iodine was then titrated against standard $(0.02 \mathrm{~N})$ sodium thiosulphate solution using starch as indicator. Blank experiment was made by treating of $100 \mathrm{~mL}$ distilled water in the same way explained above. The freshly prepared $\mathrm{KMnO}_{4}$ solution is allowed to settle the precipitate in the solution which is usually $\mathrm{MnO}_{2}$ which is often present in potassium permanganate used, as well as, distilled water may contain some organic contaminants which may reduce permanganate to $\mathrm{MnO}_{2}$, therefore permanganate solution should keep for 7 to 10 days after preparation and before use in titration.

The amount of oxidizable organic matter was calculated according to the following equation:

$$
\text { OOM as } \mathrm{mg} \mathrm{O}_{2} / \mathrm{L}=[(\mathrm{B}-\mathrm{S}) \times \mathrm{N} \times 8000] / \mathrm{V}
$$

Where:

$\mathrm{B}$ : volume of the thiosulphate used for the blank $(\mathrm{mL})$,

$\mathrm{S}$ : volume of the thiosulphate used for sample $(\mathrm{mL})$,

$\mathrm{N}$ : normality of the thiosulphate,

$\mathrm{V}$ : volume of the sample $(\mathrm{mL})$.

\subsection{Determination of Salinity [10]}

The burette of $0.21 \mathrm{M} \mathrm{AgNO}_{3}$ (3.7 $\mathrm{g}$ from Silver nitrate in 
$100 \mathrm{~mL}$ distilled water) and in the volumetric flask $10 \mathrm{~mL}$ from sea water (sample) and $5 \mathrm{~mL} \mathrm{~K}_{2} \mathrm{CrO}_{4}$ (3.5 g from Potassium Chromate in $1 \mathrm{~L}$ distilled water). Start titration till the colour of all solution change to the colour of orange.

\subsection{Determination of Phenol in Seawater}

Phenol was determined according to according to Ref.[11]. $100 \mathrm{~mL}$ of sample or standards to $2 \mathrm{~mL}$ of buffer solution (16.9 $\mathrm{g} \mathrm{NH}_{4} \mathrm{Cl}$ in $143 \mathrm{~mL}$ conc. $\mathrm{NH}_{4} \mathrm{OH}$ and dilute to $250 \mathrm{~mL}$ with distilled water) and mix. The $\mathrm{pH}$ of the sample and standards should be $10 \pm 0.2$. Add $2.0 \mathrm{~mL} 4$-aminoantipyrine (4AAP) solution ( $2 \mathrm{~g}$ of 4AAP in $100 \mathrm{~mL}$ distilled water) and mix. Then to the solution $2.0 \mathrm{~mL}$ potassium ferricyanide solution $\left(8 \mathrm{~g}\right.$ of $\mathrm{K}_{3} \mathrm{Fe}(\mathrm{CN})_{6}$ in $100 \mathrm{~mL}$ distilled water) and mix. After 15 minutes read absorbance at $510 \mathrm{~nm}$.

\subsection{Determination of Phosphate $\left(\mathrm{PO}_{4}\right)$ in Water Samples [10]}

The Reagent A was prepared by adding $10 \mathrm{~mL}$ from ammonium molybdate solution ( $15 \mathrm{~g}$ of ammonium molybdate in $500 \mathrm{~mL}$ distilled water) to $25 \mathrm{~mL}$ from sulphuric acid solution $(140 \mathrm{~mL}$ of concentrated sulphuric acid to $900 \mathrm{~mL}$ distilled water) and $10 \mathrm{~mL}$ from ascorbic acid solution $(1.5 \mathrm{~g}$ of ascorbic acid to $27.8 \mathrm{~mL}$ distilled water) were added and finally adding $5 \mathrm{~mL}$ from potassium antinayl-tartarate solution $(0.34 \mathrm{~g}$ of potassium antinayl-tartarate in $250 \mathrm{~mL}$ distilled water). During the analysis, $3 \mathrm{~mL}$ from the Std. solutions or sample were taken with $0.2 \mathrm{~mL}$ of reagent $\mathrm{A}$. after 15 minutes for colour developments, the spectrophotometer was used for analysis at wavelength $885 \mathrm{~nm}$.

\subsection{Determination of Reactive Silicate [10]}

Reducing reagent was prepared by mixing of $100 \mathrm{~mL}$ of metol-sulphite solution (1.2 g of anhydrous sodium sulphite, $\mathrm{Na}_{2} \mathrm{SO}_{3}$, were dissolved in $100 \mathrm{~mL}$ of distilled water and then $2 \mathrm{~g}$ of metol (p-methylaminophenol sulphate) was added. After the metol has dissolved the solution was filtered through a No. 1 Whatman filter paper) with $60 \mathrm{~mL}$ of oxalic acid solution $\left(25 \mathrm{~g}\right.$ of oxalic acid dihydrate $(\mathrm{COOH})_{2} \cdot 2 \mathrm{H}_{2} \mathrm{O}$, in $250 \mathrm{~mL}$ of distilled water). Then slowly, adding with mixing, $60 \mathrm{~mL}$ of the $50 \%$ sulphuric acid solution and make the mixture to a volume of $300 \mathrm{~mL}$ with distilled water. During the analysis $10 \mathrm{~mL}$ of molybdate solution $(4.0 \mathrm{~g}$ of ammonium paramolybdate, $\left(\mathrm{NH}_{4}\right)_{6} \mathrm{MO}_{7} \mathrm{O}_{24} \cdot 4 \mathrm{H}_{2} \mathrm{O}$ were dissolved in $300 \mathrm{~mL}$ of distilled water. Then $12.0 \mathrm{~mL}$ of concentrated hydrochloric acid (12N, sp gr 1.18) was added, after mixing for $1 \mathrm{~min}$, the volume has made to $500 \mathrm{~mL}$ by distilled water) were added to a dry $50-\mathrm{mL}$ measuring cylinder fitted with a stopper. Pipette $25 \mathrm{~mL}$ of the seawater sample into the cylinder, stopper, mix the solutions, and allow the mixture to stand for $10 \mathrm{~min}$. add the reducing reagent rapidly so as to make the volume exactly $50 \mathrm{~mL}$ and mix immediately. Allow the solution to stand for $2-3 \mathrm{hr}$ to complete the reduction of the silicomolybdate complex. Read the extinction at $810 \mathrm{~nm}$ in a spectrophotometer.

\subsection{Determination of Nitrite $\left(\mathrm{NO}_{2}\right)$ and Nitrate $\left(\mathrm{NO}_{3}\right)$ [10]}

For nitrite $3 \mathrm{~mL}$ of sample or Std. solutions were added to $0.3 \mathrm{~mL}$ from sulphanilamide solution $(0.5 \mathrm{~g}$ in $5 \mathrm{~mL}$ concentrated hydrochloric acid $(\mathrm{HCl})$ to $30 \mathrm{~mL}$ distilled water after the sulphanilamide dissolved. The solution made to $50 \mathrm{~mL}$ by distilled water) and left for 5 minutes and then $0.3 \mathrm{~mL}$ from $\mathrm{N}$-(1-Naphthyl)-ethylenediamine di hydrochloric $(0.1 \mathrm{~g}$ in $100 \mathrm{~mL}$ distilled water) was added and left it for 15 minutes for colour development. The spectrophotometer for analysis at wavelength $543 \mathrm{~nm}$ was used.

$\mathrm{NO}_{3}$ was reduced to $\mathrm{NO}_{2}^{-}$with hydrazine sulfate. The $\mathrm{NO}_{2}$ (originally present) plus reduced $\mathrm{NO}_{3}$ is determined by diazotization as described above.

\subsection{Determination of Ammonia $\left(\mathrm{NH}_{4}\right)$ in Water Samples [10]}

$10 \mathrm{~mL}$ of sample to $0.4 \mathrm{~mL}$ of phenol solution $(20 \mathrm{~g}$ of phenol in $200 \mathrm{~mL}$ of $95 \%(\mathrm{~V} / \mathrm{V})$ ethanol), from a pipette, swirl the solution, and then sequentially add $0.4 \mathrm{~mL}$ of sodium nitroprusside solution (1.0 $\mathrm{g}$ of sodium nitroprusside $\mathrm{Na}_{2} \mathrm{Fe}(\mathrm{CN})_{5} \mathrm{NO} .2 \mathrm{H}_{2} \mathrm{O}$ in $200 \mathrm{~mL}$ of de-ionized water) and 1 $\mathrm{mL}$ of oxidizing solution (Mix $100 \mathrm{~mL}$ of alkaline reagent (20 $\mathrm{g}$ of sodium citrate and $1 \mathrm{~g}$ of sodium hydroxide in 100 $\mathrm{mL}$ of de-ionized water) with $25 \mathrm{~mL}$ of sodium hypochlorite solution), mixing after each addition. Allow the flask to stand at a temperature between $20 \mathrm{C}$ and $27^{\circ} \mathrm{C}$ for 1 hour. The top of the flask should be covered with aluminum foil at this stage to lessen the contamination by atmospheric ammonia. Read the extinction at $630 \mathrm{~nm}$ in a spectrophotometer.

\subsection{Determination of Sodium and Potassium in Water Using Flame Photometer [12]}

The concentrations of $\mathrm{Na}$ and $\mathrm{K}$ in seawater samples were determined by using Jenway flame photometer models PFP7. The standard solution was prepared by dissolving $0.7915 \mathrm{~g}$ $\mathrm{KCl}$ and $0.4715 \mathrm{~g} \mathrm{NaCl}$ in $1 \mathrm{~L}$ distilled water to produce a solution of $500 \mathrm{ppm} \mathrm{K}$ and $250 \mathrm{ppm} \mathrm{Na}$. this solution was used as a stock solution and diluted to prepare std. solution used in the analysis. By plotting a graph of display reading (intensity) against standards concentrations and then from the sample reading, the concentration of sample can be calculated from the calibration plot.

\section{Results and Discussion}

\subsection{Physical Parameters}

\subsubsection{Temperature (T)}

The mean values of the temperature recorded in the sea water of the studied sites vary between $17.4^{\circ} \mathrm{C}$ and $19.5^{\circ} \mathrm{C}$ while the highest temperature $\left(30.1^{\circ} \mathrm{C}\right)$ recorded at Power station (11) and that was the reason for higher seawater temperatures in southern part of Tobruk gulf (Table 1). According to the results, we note that the sea water temperature (exception power station site) at the site level is 
within the norm (below $30^{\circ} \mathrm{C}$ ) which is considered as the limit value of direct rejection in the receiving environment [1].

Table 1. Seawater temperatures pHs and transparency in all samples sites.

\begin{tabular}{llll}
\hline Sample No. & $\begin{array}{l}\text { Seawater } \\
\text { Temperature }\left({ }^{\circ} \mathbf{C}\right)\end{array}$ & $\begin{array}{l}\text { Seawater } \\
\mathbf{p H}\end{array}$ & $\begin{array}{l}\text { Seawater } \\
\text { Transparency }(\mathbf{m})\end{array}$ \\
\hline 1 & 17.4 & 8.5 & 6 \\
2 & 17.4 & 8.4 & 6 \\
3 & 17.5 & 8.5 & 3 \\
4 & 17.5 & 8.3 & 4 \\
5 & 18.5 & 8.5 & 2 \\
6 & 18.3 & 8.4 & 1.5 \\
7 & 18.2 & 8.5 & 2 \\
8 & 18.5 & 8.5 & 1.5 \\
9 & 18.4 & 8.6 & 2 \\
10 & 18.4 & 8.3 & 3 \\
11 & 30.1 & 8.2 & 3 \\
12 & 18.7 & 8.5 & 7 \\
13 & 17.9 & 8.5 & 9 \\
14 & 19.5 & 8.5 & 8 \\
15 & 17.4 & 8.5 & 9 \\
\hline
\end{tabular}

\subsection{2. $\mathrm{pH}$}

The $\mathrm{pH}$ is an important parameter which represents the degree of ionization of the medium studied; it gives us an indication on the level of the pollution of the water. It should be strictly monitored during the sampling period. The average of $\mathrm{pH}$ values recorded in this study ranged from 8.2 to 8.5 (Table 1). The results obtained remain in the global standards which recommend a $\mathrm{pH}$ of the discharges comprised between 6.5 and 8.5 [1].

\subsubsection{Transparency}

Monitoring of Secchi depth provides information of water transparency that is used for assessing direct effects of pollution in seawater. The average of transparency values recorded in this study ranged from 1.5 to $9 \mathrm{~m}$ (Table 1). It was clear that the area surrounding swage discharge pipes is affected and as the distance increases far away from them the transparency become well. Secchi depth is influenced by dissolved and/or colloidal inorganic and organic substances as well as total suspended solids.

\subsubsection{Dissolved Oxygen}

Dissolved oxygen is a very useful parameter to indicate the quality of the water; it is considered one of the parameters most sensitive to pollution. Its value gives information on the state of water pollution. The dissolved oxygen analyzes performed on seawater samples ranged from $2.78 \mathrm{mg} / \mathrm{L}$ to $5.12 \mathrm{mg} / \mathrm{L}$. Recorded values ranged from $5.12 \mathrm{mg} / \mathrm{L}$ at the surface in diving club to a low of $2.78 \mathrm{mg} / \mathrm{L}$ near the power station site (Figure 2).

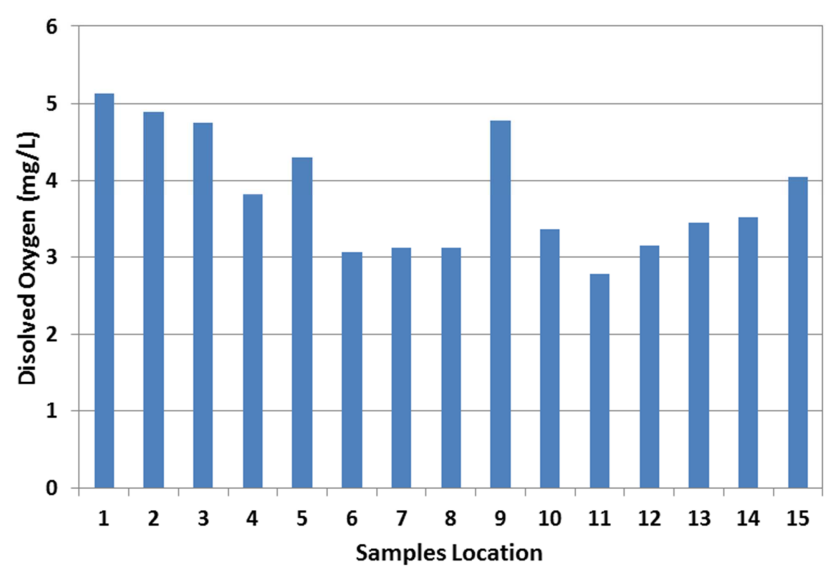

Figure 2. Quantities of dissolved oxygen ( $\mathrm{mg} / \mathrm{L})$ in Tobruk gulf.

DO measurements were utilized to examine if oxygen reached potential harmful levels to fish or benthic in fauna. Site 1 (Diving club) consistently recorded higher DO concentrations than the other stations consistent with its proximity to the open sea and location within a narrow portion of the north Tobruk gulf that promotes increased current velocities and mixing. On the other hand the lowest DO at power station site where the temperature is high and lower exchange of water at this site compared with site 1 . Maximum amount of oxygen in clean water is about $9 \mathrm{mg} / \mathrm{L}$. Prolonged exposure to low dissolved oxygen levels (less than 5 to $6 \mathrm{mg} / \mathrm{L}$ oxygen) may not directly kill an organism, but will increase its susceptibility to other environmental stresses [13]. Exposure to less than 30\% saturation (less than $2 \mathrm{mg} / \mathrm{L}$ oxygen) for one to four days may kill most of the aquatic life in a system [13].

\subsubsection{Suspended Matter}

The suspended matter represents all the mineral and organic particles contained in the waters. High levels of suspended solids can be considered a form of pollution [14]. The results obtained during this study reveal very high concentrations in some sites. For the samples obtained, the mean values recorded ranged from $8.0 \mathrm{mg} / \mathrm{L}$ to $313 \mathrm{mg} / \mathrm{L}$ (Figure 3).

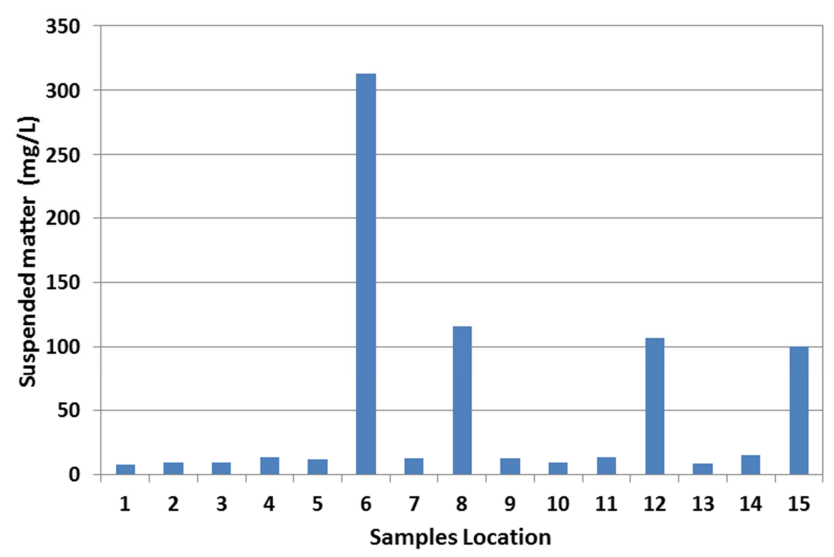

Figure 3. Suspended matter $(\mathrm{mg} / \mathrm{L})$ in Tobruk gulf.

The results show that the concentrations of the suspended 
solids in sites $6,8,12$ and 15 were far exceed the national standards defined $(35 \mathrm{mg} / \mathrm{L})$. These concentrations are probably caused by the boats emptying, sewage and urban domestic waste that are rich in colloidal matter of mineral or organic origin.

\subsection{Chemical Parameters}

\subsubsection{Biological Oxygen Demand (BOD)}

Biochemical oxygen demand (BOD) is a useful parameter for assessing the biodegradability of dissolved organic matter in water. Recorded BOD values ranged from $1.24 \mathrm{mg} / \mathrm{L}$ at the surface in sewage discharge tube to a high of $6.45 \mathrm{mg} / \mathrm{L}$ near the diving club site (1) (Figure 4). Site 1 (Diving club) consistently recorded higher BOD concentrations than the other stations consistent with its proximity to the open sea and location within a narrow portion of the north Tobruk gulf that promotes increased current velocities and mixing.

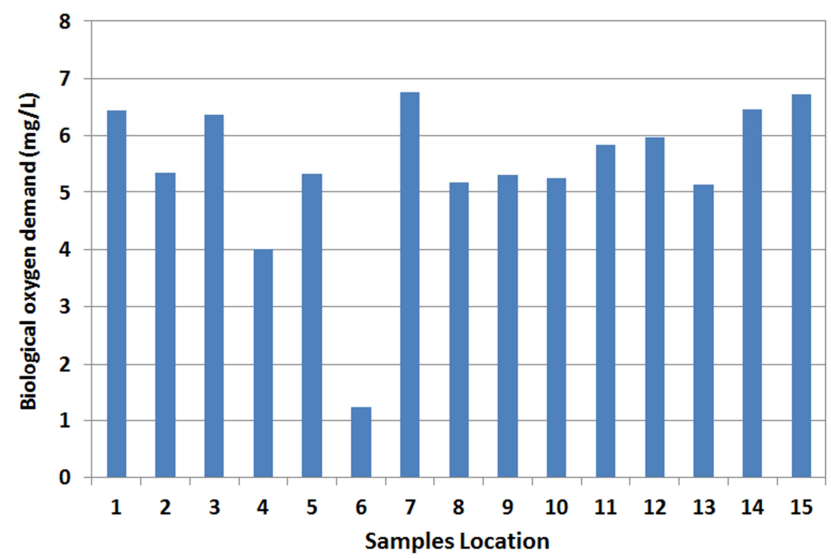

Figure 4. Biological oxygen demand (BOD) in Tobruk gulf.

The high BOD in the coastal water might probably be as a result of the presence of strong contents of suspended matter introduced by ballast water discharges and riverine input of oxygen demanding wastes, which reduced the quantity of oxygen through oxidation reaction, similar observation have been made by Voudrias and Smith [15].

\subsubsection{Salinity and Chloride Concentrations}

Salinity representing all dissolved ions that contribute to the mass of seawater and chloride, in the form of the $\mathrm{Cl}^{-}$ion, is one of the major inorganic anions, or negative ions, in saltwater and freshwater. It originates from the dissociation of salts, such as sodium chloride or calcium chloride, in water. $\mathrm{CaCl}_{2}$ and $\mathrm{NaCl}$ salts, and their resulting chloride ions, originate from natural minerals, saltwater intrusion into estuaries, and industrial pollution [16]. Chloride concentration in Tobruk gulf selected sites ranged between 19.0-21.47 ppt. The lowest concentration was observed in fishing port site, while the highest concentration was detected at Old Braga Jetty (Figure 5).

Salinity is the total of all non-carbonate salts dissolved in water. Unlike chloride $\left(\mathrm{Cl}^{-}\right)$concentration, salinity is a measure of the total salt concentration, comprised mostly of $\mathrm{Na}^{+}$and $\mathrm{Cl}^{-}$ions. Even though there are smaller quantities of other ions in seawater (e.g., $\mathrm{K}^{+}, \mathrm{Mg}^{2+}$, or $\mathrm{SO}_{4}{ }^{2-}$ ), sodium and chloride ions represent about $91 \%$ of all seawater ions. Salinity is an important measurement in seawater. Salinity concentration in Tobruk Golf selected sites ranged between 35.35-42.71 ppt. The lowest concentration was observed in fishing port site, while the highest concentration was detected at Power station site.

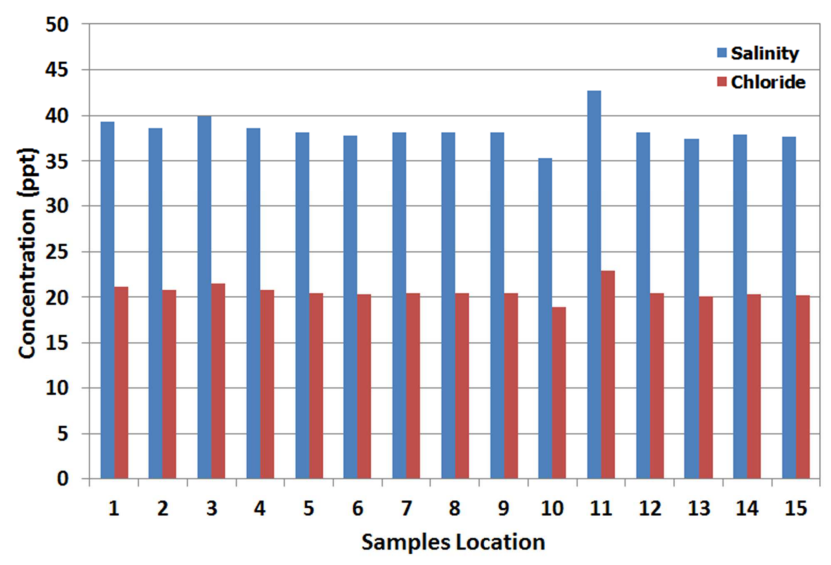

Figure 5. Salinity and chloride concentration in Tobruk gulf.

\subsubsection{Ammonia Concentrations}

Results from ammonium analysis in seawater samples show concentrations renged from $4.5 \mu \mathrm{g} / \mathrm{L}$ to $342.6 \mu \mathrm{g} / \mathrm{L}$ (Figure 6). The ammonium ion, $\mathrm{NH}^{4+}$, is the reduced form of nitrogen. It comes mainly from the decomposition of natural proteins contained in phytoplankton and microorganisms. It may also come from the supply of purified urban effluents or industrial discharges. The high levels of ammonium northern side of Tobruk gulf and especially in site 6 can be explained by the enrichment of this site in this nitrogen compound, which results from the discharges pipes of domestic and industrial wastewater.

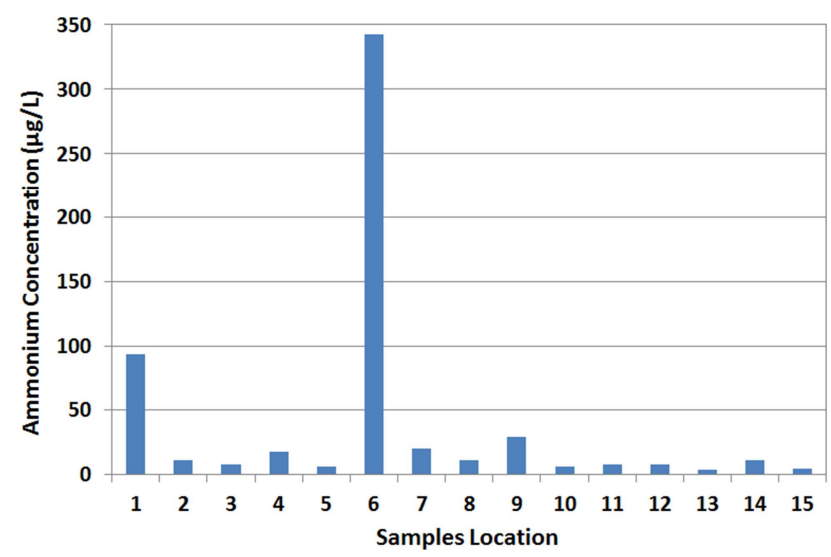

Figure 6. Ammonia concentrations in Tobruk gulf.

The presence of ammonia nitrogen in surface water usually indicates domestic pollution. Free ammonia is highly toxic to aquatic life. It kills in aquariums at very low amounts. Any level above $20 \mu \mathrm{g} / \mathrm{l}$ is considered harmful. Ammonia is very toxic to marine fish. The mechanisms of toxicity are complicated and are an active area of continued investigation 
by researchers. Its effects include damage to the gills, resulting in poor gas exchange, ion regulation and blood $\mathrm{pH}$ regulation [17].

\subsubsection{Nitrite and Nitrate Concentrations}

Average concentrations of nitrite in seawater range from $0.5 \mathrm{mg} / \mathrm{L}$ to $23.6 \mu \mathrm{g} / \mathrm{L}$. The low concentrations of nitrites found in the waters studied could be explained by the fact that the nitrite ion $\left(\mathrm{NO}_{2}\right)$ is an intermediate between ammonium and nitrates and is unstable in the presence of oxygen, whose concentration is generally much lower than that of the two forms which are related to it, nitrate ions and ammonium. The lowest concentration in this study was observed in San Jorge beach site (2); Civil port (Municipal deranges tube) site (5), while the highest concentration was detected at Gulf Hotel (Small municipal derange tube 4) site (8); Suction Box for power station site (14) (Figure 7).

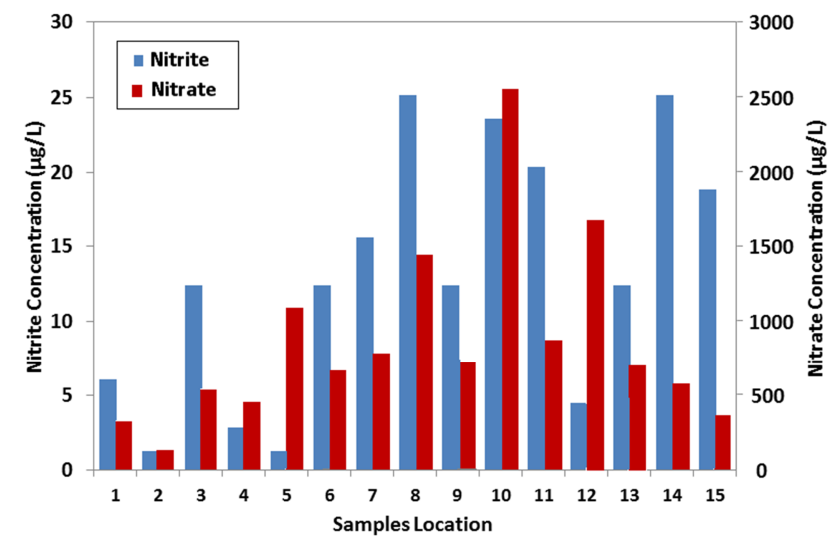

Figure 7. Nitrite and Nitrate concentrations in Tobruk gulf.

Nitrogen is present in the marine environment in various forms. Nitrate is the principal form of fixed dissolved inorganic nitrogen assimilated by organisms, although certain organisms can utilize nitrite, ammonium or even dissolved molecular nitrogen [18]. Nitrate concentration in Tobruk gulf selected sites ranged between 12.29-344.73 $\mu \mathrm{g} / \mathrm{L}$. The lowest concentration was observed in San Jorge beach site (2); while the highest $(344.72 ; 233.41 ; 181.41 ; 150.53 \mu \mathrm{g} / \mathrm{L})$ concentrations were detected at Fishing port; New Braga Jetty for petroleum refinery products; Gulf Hotel (Small municipal derange tube 4; Civil port (Sewage discharge tube (1) sites respectively (Figure 7).

\subsubsection{Silicate Concentrations}

Silicate is an important factor as a major nutrient for diatoms; the lowest content may be due to the uptake of silicate by phytoplankton as well as to the slow rate of regeneration of silicate from the sediments [19]. Silicate concentration in Tobruk gulf selected sites ranged between $0.64-11.03 \mathrm{mg} / \mathrm{L}$. The lowest concentration was observed in Old Braga Jetty (3); while the highest (11.03 $\mathrm{mg} / \mathrm{L})$ concentration was detected at Fishing port (site 10) (Figure 8).

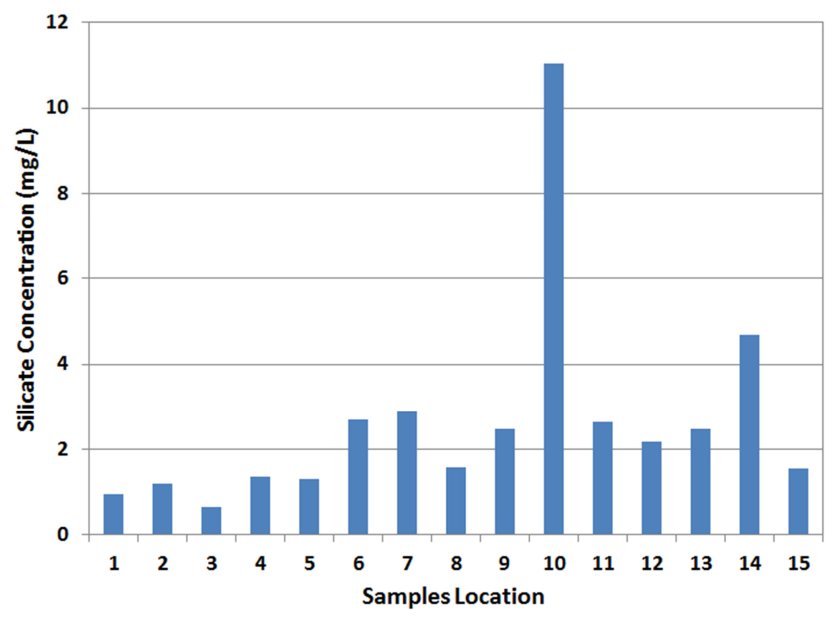

Figure 8. Silicate concentrations in Tobruk gulf.

The higher concentrations of reactive silicate were indirectly proportional to the decomposition occurred by pollution, in addition to the increase of generation rate from underlying sediments. This may be the major's factors influencing silicate variability in the present study. It is interesting to observe that the higher concentrations of reactive silicate are controlled by the content of dissolved oxygen. This can be explained by the fact that in very badly oxygenated area, the decomposition of siliceous compounds increases under the effect of aerobic bacteria [19].

\subsubsection{Phosphate Concentrations}

Analyses of phosphate in the samples collected ranged concentrations. The mean values obtained are between Phosphate concentrations between 0.00-188.7 $\mu \mathrm{g} / \mathrm{L}$. The lowest concentration was observed in Old Braga Jetty (3); Civil port (5); Old cool port (9); New Braga Jetty for petroleum refinery products (12); Heraga Jetty for crude oil loading (13); Suction Box for power station (14); Umm ElShawesh transit (15), while the highest $(188.7 \mu \mathrm{g} / \mathrm{L})$ concentration was detected at Sewage discharege tube(2) (site 6) (Figure 9). However, phosphate concentration were within the accepted range which is less than $2000 \mu \mathrm{g} / \mathrm{L}[1]$.

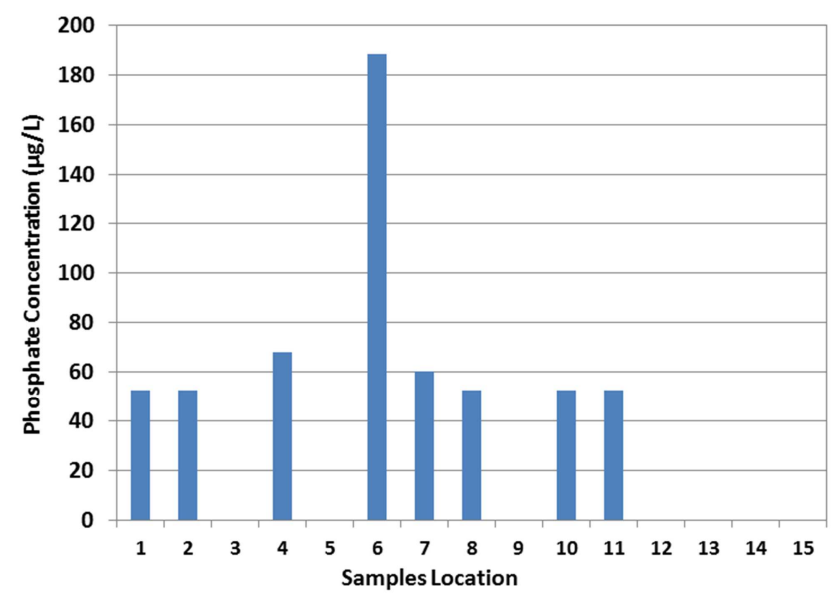

Figure 9. Phosphate concentrations in Tobruk gulf. 


\subsubsection{Phenol Concentrations}

Phenol concentrations in Tobruk gulf selected sites ranged between 118.1-506.7 $\mu \mathrm{g} / \mathrm{L}$. The lowest concentration was observed in Old Braga Jetty (3) and Civil port (5) while the highest $(506.7 \mu \mathrm{g} / \mathrm{L})$ concentration was detected at El-Heraga Jetty for crude oil loading (site 13) (Figure 10). The high concentration of phenol detected in El-Heraga Jetty for crude oil was expected in this site, as phenol is an indication to petroleum pollution.

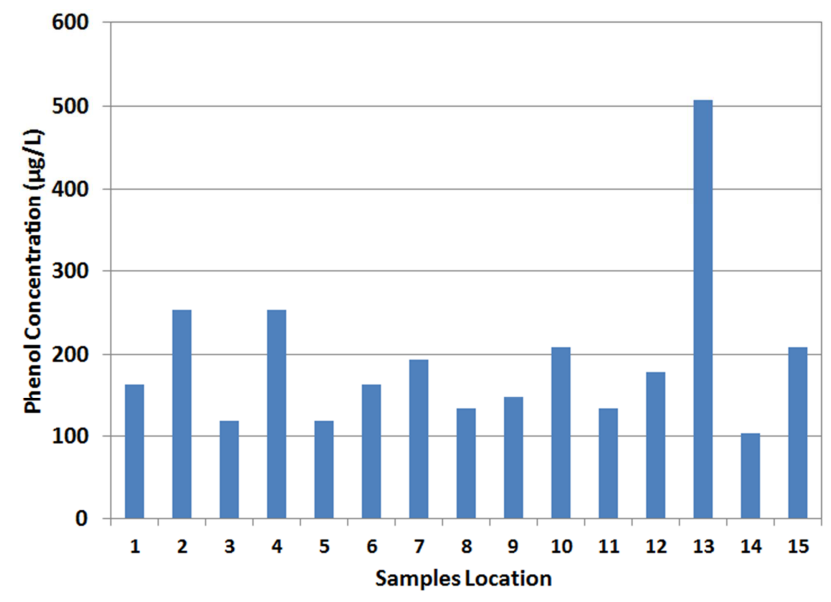

Figure 10. Phenol concentrations in Tobruk gulf.

\subsubsection{Oxidizable Organic Matter (OOM) Concentrations}

Average values of OOM in seawater range from $0.41 \mathrm{mg} / \mathrm{L}$ to $7.3 \mathrm{mg} / \mathrm{L}$ (Figure 11). The results obtained allow us to observe the variations of the organic matter in all sites of the study area. The increase in OOM content at study sites is due to the high levels of organic matter discharged into the environment. This high OOM content apart from site (2) is explained by the pollutant load carried by the anthropogenic coastal discharges of the waste water discharged at the sites studied.

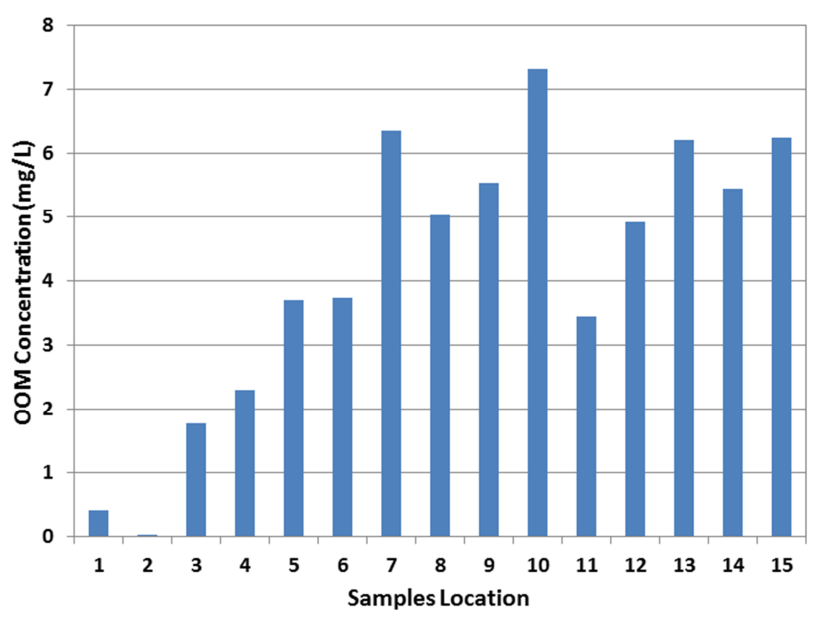

Figure 11. OMM concentrations in Tobruk gulf.

\subsubsection{Sodium and Potassium Concentrations}

Sodium concentrations in Tobruk gulf selected sites ranged between $5100-7980 \mathrm{mg} / \mathrm{L}$. The lowest concentration was observed in Cornish beach center (Sewage discharge tube(3) (site 7); Fishing port (site 10) and Suction Box for power station (site 14) while the highest $(7.98 \mathrm{~g} / \mathrm{L})$ concentration was detected at Diving club (site 1) (Figure 12).

The fluctuation of sodium in the selected site depends on the site location and the activity posed at this site. Derange of fresh water dilutes the sea water and reduced sodium concentration i.e. at power station suction box. The high concentration of sodium at site 1 where is location at water movement in open sea. Potassium concentrations in Tobruk gulf were found in the range $490-1540 \mathrm{mg} / \mathrm{L}$. The lowest concentration was observed in Old cool port (site 9); Fishing port (site 10) while the highest $(1540 \mathrm{mg} / \mathrm{L})$ concentration was detected at 12: New Braga Jetty for petroleum refinery products (site 12) (Figure 12). The changes in potassium detected in Tobruk gulf sites variation is due to the site location and the activity at or near this site. It is clear that the potassium produced as petroleum processing by products has a huge impact in the concentrations of potassium in Tobruk gulf.

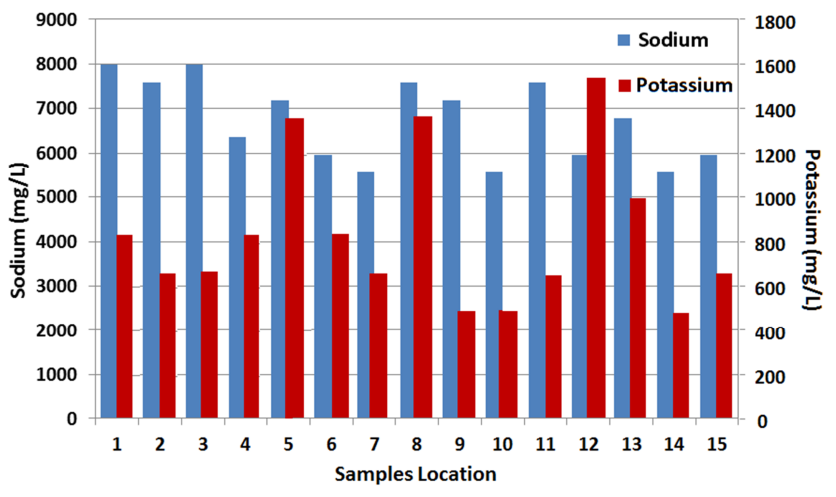

Figure 12. Sodium and Potassium concentrations in Tobruk gulf.

\section{Conclusion}

Three different sources (sewage, ballast water and petroleum port) can lead to marine pollution or a serious problem in the Mediterranean Sea, especially in oil countries in the process of industrialization like Libya. With the absence of stations and sewage treatment systems in these countries, wastewater is discharged into the sea without any prior treatment, leading to degradation of the sanitary quality of coastal waters and disruption of marine ecosystems. This work deals with an assessment of the state of marine pollution along with Tobruk golf as a case study. Spacetemporal monitoring of several physicochemical tracers has given the image of a relatively intense pollution which results in a large organic and mineral load. The results of the pollution indicator parameters reveal that the site studied is polluted by the wastewater discharged and some petroleum by products. Analysis of nutrient salts shows the richness of the site studied in nutrients imported by wastewater discharges. However, continuous exposure can degrade the marine ecosystem and affect wildlife and marine life. These results show the need for prior treatment of raw wastewater, biological treatment should be considered to improve their 
quality to the required standards and to meet the expectations of the public authorities with regard to protection of the environment and human health.

\section{References}

[1] F. Redouane, L. Mourad, Journal of Pollution Effects \& Control, 5 (2017) 1-5.

[2] D. Belghyti, Y. Guamri, G. Ztit, M. Uahidi, M. Joti, Afri Sci, 5 (2009) 199-216.

[3] B. I. Briton, B. Yao, G. Ado, Journal of Applied Science and Environmental Management 11 (2007) 173-179.

[4] T. A. Adesalu, D. I. Nwankwo, International Journal of Biodiversity and Conservation, 2 (2010) 33-36.

[5] I. M. Suthers, D. Rissik, A Guide to their Ecology and Monitoring for Water Quality, 2nd ed., CSIRO Publishing, Victoria, 2009.

[6] S. Badylak, E. J. Phlips, J. of Plank. Res., 26 (2004) 12291247.

[7] M. J. Laamanen, J. of Plank. Res., 19 (1997) 1385-1403.

[8] H. G. Marshall, L. Burchardt, R. Lacouture, J. of Plank. Res., 27 (2005) 1083-1102.
[9] J. Høkedal, K. Sørensen, Ocean Science, 10 (2014) 177-199.

[10] T. R. Crompton, Analysis of Seawater, 1 ed., Springer, New York, 2006.

[11] ASTM, Annual Book of Standards, Part 31, "Water", Standard D 1783-70, p553, 1976.

[12] S. B. Deal, Analytical Chemistry 26 (1954) 598-599.

[13] ILRI, Monitoring and Analysis of Drainage Water Quality Project. Technical Report No.52., in, Drainage Research Institute The Netherlands 2000.

[14] F. Redouane, L. Mourad, J Air Wast Manage Assoc, 66 (2016) 260-266.

[15] E. Voudrias, C. Smith, Estuarine Coastal and Shelf Science 22 (1986) 271-284.

[16] G. Chi, C. Xue, Geoscience Frontiers, 2 423-438.

[17] F. B. Eddy, Journal of Fish Biology, 67 (2005) 1495-1513.

[18] M. D. Patey, M. Rijkenberg, P. J. Statham, M. C. Stinchcombe, E. P. Achterberg, M. Mowlem, Trends in Analytical Chemistry, 27 (2008) 169-182.

[19] M. Okbah, S. El-Gohary, Medit. Mar. Sci, 3 (2002). 